\title{
THE IMPORTANCE OF INTENSIVE TREATMENT IN THE REHABILITATION PROCESS OF CHILDREN WITH AUTISM SPECTRUM DISORDER
}

\begin{abstract}
Autism is a pervasive developmental disorder defined by the presence of abnormal and impaired development manifested before the third year of life with a specific type of pathological functioning in all three areas of social interactions, communication and by repetitive behaviour (WHO, 2018).

The starting point of this study is whether and to what extent the intensive treatment affects the condition of each child with an autism spectrum disorder. The results from the research demonstrate the existence of a significant improvement of the condition of children with autism spectrum disorder in intensive treatment during the assessment after a certain period of time.
\end{abstract}

Keywords: INTENSIVE TREATMENT, AUTISM, AUTISM SPECTRUM DISORDER

\section{Introduction}

Autism as a specific condition requires a mandatory, continued and intensive treatment resulting with improvement of the overall condition of the children. Intensive therapies require more hours of therapy during the week and include behavioural, developmental and educational objectives. According to many research studies, it has been proved that early interventions and early treatments affect positively on the condition of the children, and therefore each child with an autism spectrum disorder should be treated continuously.

It is of great importance for the child to start the treatments, led by a competent person, as early as possible. Each therapy has an objective to stimulate the development of the child. Best results are achieved if the treatment starts at the age of 3 to 4 years, and this fact by itself warns about the high significance of early assessment and early treatment.

\section{Methodology}

The subject of this research is the influence of an early intensive treatment on the condition of children with autism spectrum disorders. 
The purpose of this research is to examine to what extent children with autism spectrum disorder benefit from an early intensive treatment and its positive impacts on their overall condition. The research is retrospective and comparative. It is based on already determined and completed researches subject to comparative investigations, pre-treatment and post-treatment condition.

Within this research study two research segments have been performed: an initial assessment and a control assessment after a period of three months. The research included 36 children with autism spectrum disorder, out of which 6 girls and 30 boys. The children were divided into two groups, the first group included children in social packages, i.e. children without any prior treatment (25 children); the second group included children at the same age which have been treated for a period of one year with an intensive continued treatment in an Association of citizens for treatment of persons with autism spectrum disorder "In My World".

The initial assessment - the first assessment of the condition of the examinees has been performed by using the CARS scale with the children from the first group without any prior treatment and with the second group of children with a continued treatment of one year.

The control assessment - i.e. the second assessment has been performed on the same groups of children. The second assessment was carried out in order to compare the results obtained with the continued treatment of children included in the social packages to the results of the children undergoing an intensive treatment for a period of one year.

During our research we used an assessment technique including the Childhood Autism Rating Scale (CARS - Childhood Autism Rating Scale, Schopler).

The assessment scale is composed of 15 items used to rate the behaveour of the child and yields a composite score ranging from normal behaveour to severe deviations. The scale can provide the following results in terms of children behaviour:

- Absence of autism (15 - 29.5)

- Mildly autistic (30 - 36.5)

- Severely autistic (37-60)

Each item is scored on a scale ranging from 1 to 4 with the following interpretations:

-1 point - the behaviour does not deviate from the standard behaveour of children at the same age;

- 2 points - mild deviations compared to children at the same age;

-3 points - moderate deviations compared to children at the same age;

-4 points - severe deviations compared to children at the same age. 
This group includes 25 children with autism spectrum disorder without any prior treatment. The results from the first and the second assessments regarding the impact of intensive treatment on the condition of the children with autism spectrum disorder are presented in figure 1 and 2 .

From the graphic overview of all 15 items, it is obvious the intensive treatment has positive impact on the condition of children with autism spectrum disorder.

This group includes 11 children with autism spectrum disorder who previously had continued intensive treatment for a longer period of time.

From the graphic overview of all 15 items, it is obvious the intensive treatment has positive impact on the condition of children with autism spectrum disorder. For this group as well there is a statistically significant difference in terms of importance $\mathrm{p}<0,001$.

With comparative display on the value of the standardisation of a deviation on respondents before and after treatment, fixed values and mainly comparison with T-Test, it can be recorded that by the all 15 items with whom we evaluate the behaviour there has a statistically significant difference on two evaluations of the respondents included with intensive treatment to the level of significance of the $p<0.001$, which is observed in the statistical standards of the values, as statistical evidence giving us the right to conclude that an intensive treatment brings improement to children's state.

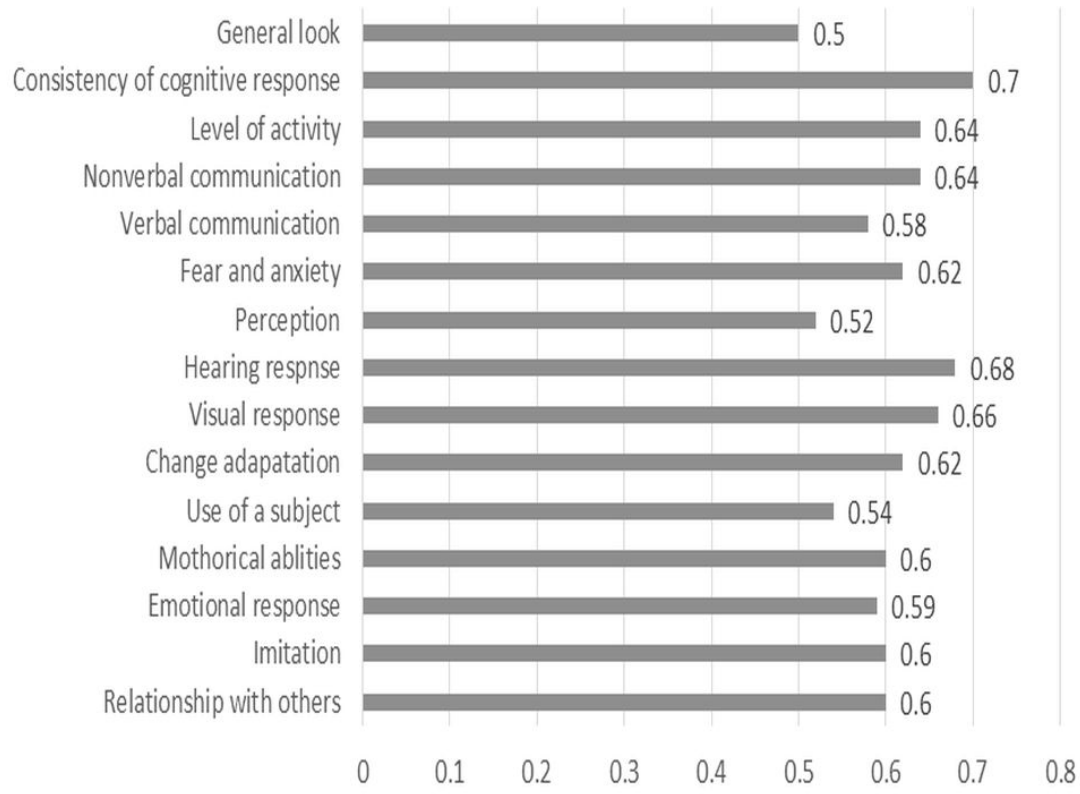

Figure 1. Difference of the first group after first and second assessment, on how intensive treatment is impacting children's state with autistic spectrum on violation on first group 


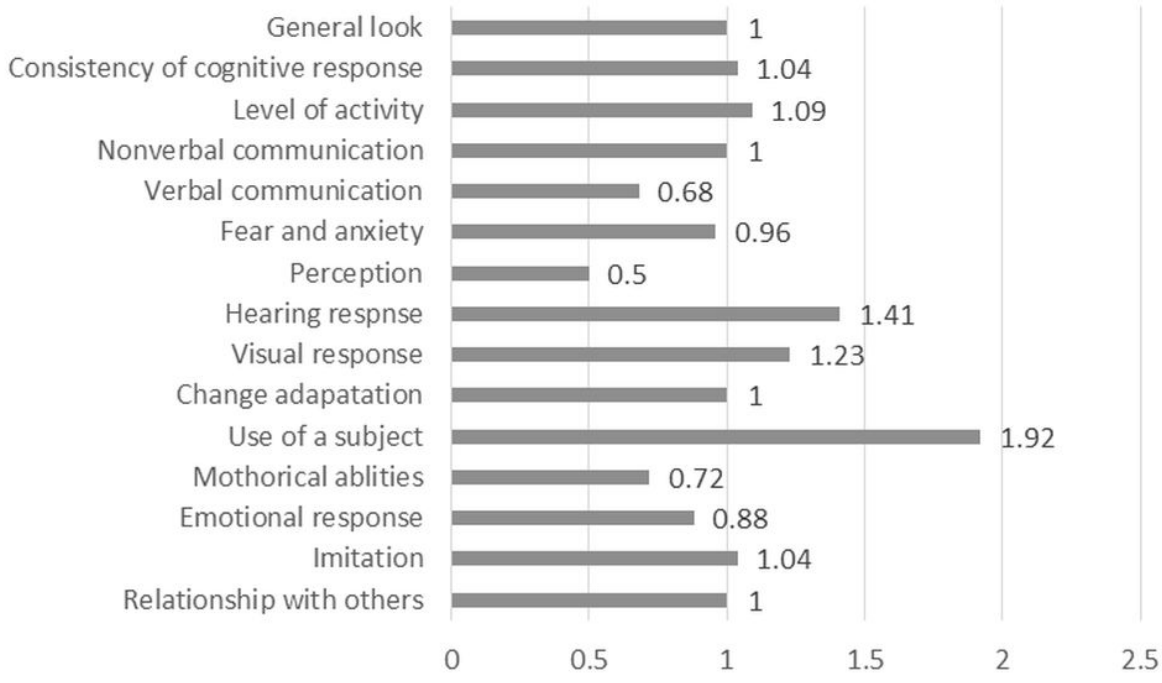

Figure 2 Difference of the second group after first and second assessment, on how intensive treatment is impacting children's state with autistic spectrum on violation on second group

According to the results, which we gathered comparing the two groups, we also made percentage of the total arithmetic value of the two groups of respondents. It can be seen now that average value is 33.54 and is in the group of mild degree of autism and during the first evaluation was 45.02 and it was falling under severe degree of autism. Based on this, we can conclude that intensive treatment positively affects the children's state with autistic spectre of disorder.

Table 1. Delta between first and second evaluation

\begin{tabular}{|c|c|c|c|c|c|}
\hline \multicolumn{6}{|c|}{ Descriptive statistics } \\
\hline & $\begin{array}{l}\text { Number of } \\
\text { respondents }\end{array}$ & Min & Max & $\begin{array}{l}\text { Middle } \\
\text { value }\end{array}$ & $\begin{array}{l}\text { Standard } \\
\text { deviation }\end{array}$ \\
\hline Evaluation 1 & 36 & 22,50 & 60,00 & 45,0200 & 11,63640 \\
\hline Evaluation 2 & 36 & 14,00 & 49,00 & 33,5400 & 11,19795 \\
\hline Total & 36 & & & & \\
\hline
\end{tabular}

\section{Discussion}

Taking into consideration the nature of the condition, the individuals with autism spectrum disorder are facing countless challenges on a daily basis. Early intervention is a systematic approach to early and continued treatment performed by a competent team and aimed at the needs of each child 
and its family. It is based on the belief that the individual and specialized treatment should start as early as possible (Landesman Ramey, Ramey \& Lanzi, 2007). Taking into account the fact that the autism spectrum points out that each child has a different condition, there is no one ideal treatment for all children. However, there are various treatments which if customized to the abilities of the child with an intensive and continued work will have a positive impact on the condition.

Geraldine Dawson and her associates have performed a research demonstrating that early intensive behavioural therapy for autism indicates improvements of not only social skills, but as well improvements related to brain activity in response to social signs, such as facial expression.

This can be considered as the first indicator linking early intensive behavioural therapy to brain function, resulting with positive behavioural changes. In 2012 a research was completed related to monitoring brain activity of 48 pre-school children, following a 2 year early intensive intervention. The intervention was started at the age of 18 to 30 months. Half of the children received intensive therapy, while the other half received routine intervention services for autism, usual for their communities. For comparison purposes, a group of children with normal development without any autism spectrum disorder was also tested.

Brain activity of the children was monitored with the use of electroencephalography machine (EEG). When showing them photographs of faces of women, it was observed that the reaction brain activity of the children with autism spectrum disorder who have received intensive therapy matches the brain activity of the children without any autistic spectrum. Their brain activities led to improvements in social behaviour, eye contact and communication. The children who received routines-based intervention services demonstrated that their brain activity displayed relative lack of attention and focus on the photographs of the faces of women. The research exhibits the unusual brain activity model of children with autism spectrum disorder.

The research further shows that children with early intensive therapy have significant gains in their cognitive, linguistic and everyday skills compared to the children who receive routines-based intervention services.

The American Academy of Paediatrics for children with autism spectrum disorder recommends an early intensive therapy starting at the age of 18 to 24 months. Despite the fact that early intensive treatment is ideal for children, many research studies suggest that adult persons with autism can benefit from intensive treatments which will further promote their social engagement.

An English study from 2014 demonstrated that after a year of intenseve treatment there was improvement of the condition of the children in terms of social and communication skills. 
The research was conducted by the Children Centre in England with the inclusion of 83 children diagnosed with autism spectrum disorder who underwent a program of early intensive therapy. The program was based on the principles of Applied Behaviour Analysis (ABA), and the children received an intensive therapy of 20 to 30 hours on a weekly basis. When the therapy started, the children were aged 1 to 3 years.

After a year of intensive treatment, the condition of the children displayed improvements in social and communication skills. These skills include improvement of their relationships with other people, imitation, interactive play and speech. In order to be able to evaluate the level of improvement of the condition of the children with intensive treatment, the researchers compared the level of skills of each child to the level of skills the children had at the beginning of the program and the skills of children at the same age with normal development. 58 examinees were included in the research.

As previously mentioned, the examinees are at the age of 1 to 3 years, and although there were improvements of the condition in all age groups, the examinees from the youngest age group displayed highest benefits within a year of intensive therapy. The children included in the program before their second birthday (11 to 12 children), had an improvement of $90 \%$ and significant positive gains; the children who started the therapy between the age of 24 and 29 months (26 to 36 children), had an improvement of $70 \%$, while the children who started intensive therapy after the age of 30 months (11 to 35 children), had an improvement of only 30\% during the year.

These findings demonstrate that early intensive treatment impacts positively on the condition of the children.

Howards and associates have conducted a research in 2014 where they compared the effects of a one-year intensive treatment of 29 children diagnosed with autism spectrum disorder. The children were divided into 2 groups, one of them had intensive behavioural treatment of 25-30 hours on a weekly basis and the second group had a not so intensive treatment of 15 to 17 hours weekly. After two years of intervention the research demonstrates that the children from the first group who had intensive treatment had significant improvement in the adaptive functioning and cognitive skills, compared to the children without an intensive treatment. The results after one year of intensive treatment demonstrate that the first group had a chance to develop normal functioning. With some children who did not achieve the desired results during the first year, succeeded to do so during the second year.

All the above mentioned researches further confirm the positive impact of the intensive treatment on the condition of the children with autism spectrum disorder. Therefore, all persons concerned should be acquainted with and try to provide an appropriate treatment for every child in order to fully use the potential and enhance their welfare. 


\section{Conclusion}

Relying on this research study, regarding the importance of the intensive treatment on the condition of children with autism spectrum disorder, we have reached the conclusion that early pre-school childhood period is the key period for setting the diagnosis, as well as for choosing the most appropriate treatment. As we all know the situation in our country is such that it does not allow every family with a family member with autism spectrum disorder to get intensive treatment, in spite of their strong desire. Although the family as a factor helps with the support of the child, nonetheless an expert person is needed to recognize and work with the strengths of the child.

Intensive treatment is the right way to make progress and create a better future for this category of children.

Following the presentation and the discussion of all data received with the analysis of the results of the research regarding the influence of the intensive treatment on the condition of children with autism spectrum disorder, we have reached the following conclusions:

-Intensive treatment affects positively the condition of the children with autism spectrum disorder;

- In order to be able to develop properly in the environment, every child should be treated with an intensive treatment;

- The time factor is crucial for the intensive treatment, the sooner the treatment starts, the better the results will be;

-Intensive treatment affects positively the relationships between people; skills;

-Intensive treatment affects positively the development of social

-Intensive treatment affects positively the improvement of verbal and non-verbal communication;

-Intensive treatment has positive effects on perception;

-Intensive treatment affects positively emotional response and imitation;

-Intensive treatment affects positively motor functions, the use of various objects, as well as the activity level;

-Intensive treatment affects positively the consistency of the cognitive response as well as the general appearance of the child with autism spectrum disorder;

-Intensive treatment affects positively the fear and the nervousness of the condition. 


\section{Recommendations}

Basic duty of every society is to provide all citizens with an active support for a healthy way of living, safer environment, applied health care, rehabilitation and community support.

- Early assessment - early treatment. This is a key rule, the sooner the problem is discovered, the sooner an appropriate treatment will be given. Timely identification of individual abilities and disabilities of the child leads to a better choice of strategies and tools which will further help the child with autism in his general development.

- Every child with an autism spectrum disorder should undergo an intensive treatment in order to improve the overall condition.

- Increased level of social protection, increase of standard and the quality of life of children with autism spectrum disorder.

- Strengthening the cooperation between various sectors and ministries with the joint purpose to improve the condition of the persons with autism spectrum disorder within all scopes of everyday life and their integration in the society.

- Awareness rising of the local authorities and their greater involvement in finding solutions for the inclusion of all children in early intensive treatment.

- Implementation of social packages as a system solution in the Law on Social Protection.

- Precise definition of the standards related to the treatment of children with autism spectrum disorder.

- Media campaign for raising the public awareness and social inclusion of children with autism spectrum disorder in the proper meaning of the word. 


\section{References}

Adiva. (2017). Sto je autizam i kako mozemo pomoci nasoj djeci, 2017. https://www.adiva.hr/zdravlje/mladi/sto-je-autizam-i-kako-mozemo-pomoci-nasoj-djeci-63/

Atun-Einy, O., M. Lotan, Y. Harel, E. Shavit, S. Burstein, and G. Kempner. (2013). Physical Therapy for Young Children Diagnosed with Autism Spectrum Disorders-Clinical Frameworks Model in an Israeli Setting. Frontiers in Pediatrics 1:19.

Autism speaks. Treatments $\mathcal{E}$ Therapies. (2010). https://www.autismspeaks.org/sites/default/files/documents/100-day kit/treatment_version_2_0.pdf

Cochrane. (2012). Rana intenzivna bihevioralna intervencija za poboljšanje funkcionalnih ponašanja i vještina u male djece s poremećajem iz spektra autizma. http://www.cochrane.org/hr/CD009260/rana-intenzivna-bihevioralna-intervencija-za-poboljsanje-funkcionalnih-ponasanja-i-vjestina-u-male

Dawson, D., Emily J. H. Jones, K. Merkle, K. Venema, R. Lowy, S. D. Kamara, F. Murias, M. Greenson, J. Winter, J. Smith, M. J. Rogers, S. J. Webb. S. (2012). Early Behavioural Intervention Is Associated With Normalized Brain Activity in Young Children With Autism. Journal of the American Academy of child \& adolescent psychiatry.

Drobnjak, B. Milošević, N. (2015). Komparativna analiza terapijskih pristupa $\mathrm{u}$ tretmanu verbalnog ponašanja dece sa autizmom. Govorno-jezički poremećaji razvojnog doba - Zbornik radova. Beograd: Udruženje logopeda Srbije.

Gabriels, R. L.\& D. E. Hill. (2007). Growing up with autism. New York: The Guilford Press.

Geretsegger, M., C. Elefant, K. A. Mössler, C. Gold. (2014). Music therapy for people with autism spectrum disorder. Cochrane Database Syst Rev. 2014 Jun 17.

Glumbić, N. (2005). Odrasle osobe sa autizmom. Beograd: Izdavačka agencija "Grad".

Glumbić, N. Brojćin, B. Đorđević, M. (2013), Rana intervencija kod dece s poremećajima autističkog spectra. Specijalna edukacija i rehabilitacija (Beograd), Vol. 12, br. 1. 103-118.

Howard, S., J. Stanislaw, H. Green, G. R. Sparkman, C. G. Cohen, H. (2014). Comparison of behaviour analytic and eclectic early interventions for young children with autism after three years. Research in Developmental Disabilities. Volume 35, Issue 12, December 2014.

Jančec, M., Šimleša, S., Frey Škrinjar, J. (2016). Poticanje socijalne interakcije putem socijalnih priča u dječaka s poremećajem iz spektra autizma. Hrvatska revija za rehabilitacijska istraživanja, 52(1), 87-99. 
MacDonald, R. Parry-Cruwys, D. Dupere, S. Ahearn, W. (2014). Assessing progress and outcome of early intensive behavioural intervention for toddlers with autism. Research in Developmental Disabilities, Volume 35, Issue 12, December 2014.

Milačić, Vidojević, I. (2008). Autizam - dijagnoza i tretman. Beograd: Fakultet za specijalnu edukaciju i rehabilitaciju.

Newson, C. P., E. Prevezer, E. \& Chandler, S. (2009). First steps in intervention with your child with autism. London and Philadelphia: Jessica Kingsley publishers.

Sansosti, F. J., A. Powell-Smith, K. J. Cowan. R. (2012). High-Functioning Autism/Asperger Syndrome in Schools. New York: The Guilford Press.

The American Academy of Paediatrics (AAP). Journal Paediatrics, 2018.

Schopler, E. J. Reichler, R. Rochen Renner, B. (1988). CARS - The Childhood Autism Rating Scale. Los Angeles, CA: Western Psychological services. 